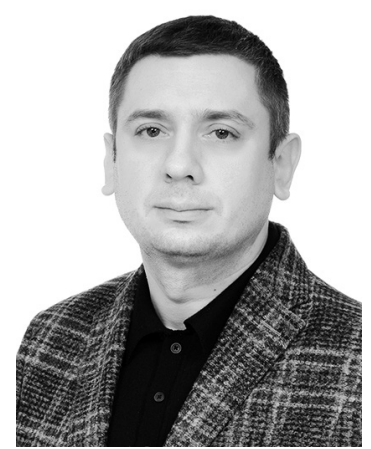

\title{
СУЧАСНА ПАРАДИГМА ЕКОНОМІЧНОї ЗЛОЧИННОСТІ
}

В умовах глобалізащї, транснаціонального співробітництва, трансформаиійних перетворень начіональної економіки негативним трендом проходить поширення економічної злочинності та криміналізачія фінансово-економічних відносин.

Визначено, що злочинність у сбері економіки - изе корислива злочинна діяльність службових осіб та інших учасників економічних відносин, спрямована на заподіяння матеріальної шкоди підприемствам, установам, організачіям різних форм власності або суб'єктам господарювання.

у статті, на основі аналізу наукових досліджень, сбормульовано основні детермінанти економічної злочинності; встановлено кореляиійні зв'язки між рівнем бінансово-економічної злочинності та низьким рівнем відповідальності за вчинення такого типу кримінальних правопорушень.

Запропоновано, імплементувати у Кримінальний кодекс України термін «кримінальні правопорушення у сбері економіки", як умисні суспільно небезпечні діяння у сбеpi права власності, встановленого порядку здійснення господарсъкої та службової дiяльності, що завдають шкоду суспільним економічним відносинам, законним правам та інтересам громадян і суб'єктів господарювання, незалежно від борм власності.

Ключові слова: економічна злочинність, злочинність в економічній сбері, кримінальні правопорушення у сфері економіки, фінансові ресурси, бінансові ризики.
Постановка проблеми

В умовах глобалізації, транснаціонального співробітництва, трансформаційних перетворень національної економіки негативним трендом проходить поширення економічної злочинності та криміналізація фінансово-економічних відносин. Актуальності проблема набула саме нині, в умовах транснаціонального співробітництва й трансформаційних перетворень національної економіки, коли негативним трендом виступає поширення економічної злочинності та криміналізація фінансово-економічних відносин.

Сучасна структура економічної злочинності охоплюе значну частину кримінальних правопорушень, що вчиняються в бюджетній сфері, адже метою таких корисливих діянь, що вчиняються у сфері економіки, усе частіше стає вилучення коштів iз державної казни у легальних формах господарської діяльності чи повноважень щодо контролю за цією діяльністю $з$ використанням службового становища посадових осіб.

\section{Мета статті}

Науковий аналіз норм чинного кримінального, процесуального законодавства, моніторинг змісту оперативно-розшукових векторів нецільового використання бюджетних коштів службовими особами. Обстеження доктринальних підходів щодо механізму протидії економічній злочинності в контексті формування теоретико-прикладних 
пропозицій і окреслення векторів боротьби 3 нецільовим використанням бюджетних коштів.

\section{Ступінь дослідженості теми}

Вивченню проблемних питань протидії кримінальним правопорушенням у бюджетній сфері у рамках кримінального, адміністративного, фінансового права, теорії управління, кримінологічної та криміналістичної наук, свої дослідження присвятили такі вчені, як П. П. Андрущенко, А. С. Беніцький, А. І. Берлач, О. О. Бондаренко, С. Г. Гуржій, А. М. Доля, О. М. Джужа, В. П. Головіна, П. Т. Гега, Т. В. Качка, Р. А. Калюжний, А. О. Клименко, Я. Ю. Кондратьєв, О. С. Користін, М. Є. Короткевич, О. В. Маркова, І. С. Мезенцева, В. М. Попович, С. В. Симовян, В. С. Щербина, В. К. Шкарупа.

Характеристику окремих видів так званих «економічних кримінальних правопорушень» у рамках оперативно-розшукової діяльності, наведено у роботах вітчизняних учених правознавців: К. В. Антонова, В. І. Василинчука, О. Ф. Долженкова, І. П. Козаченка, Д. Й. Никифорчука, С. I. Ніколаюка, В. А. Ортинського, В. Д. Пчолкіна, А. П. Скалозуба, Б. Г. Розовського та інших.

Проте, більшість праць мають «оглядовий» характер або стосуються лише загальних аспектів проблеми виявлення i розслідування кримінальних правопорушень, пов'язаних із фінансовими ресурсами, бюджетними коштами, що потребує подальших розвідок у цій площині.

\section{Виклад основного матеріалу}

Злочинність у сфері економіки - це корислива протиправна діяльність службових осіб та інших учасників економічних відносин, спрямована на заподіяння матеріальної шкоди підприємствам, установам, організаціям різних форм власності або суб'єктам господарювання.

Матеріальною ознакою злочинності у сфері економіки $є$ незаконне збагачення шляхом заподіянь матеріальної шкоди юридичним і фізичним особам, що займаються економічною діяльністю. Тому вказана зло- чинність відноситься ним до типу корисливої злочинності [1].

Сучасна структура економічної злочинності охоплює значну частину злочинів, що вчиняються в бюджетній сфері. Науковці та практики зазначають, що метою корисливих злочинів, що вчиняються у сфері економіки, усе частіше стає вилучення коштів із казни у легальних формах господарської діяльності чи повноважень щодо контролю за цією діяльністю з використанням службового становища посадових осіб.

Виділяючи особливості кримінальних правопорушень у фінансово-економічній сфері, не можна не вказати на одну з істотних причин їх вчинення - наявність високого ступеня фінансових ризиків та недостатнє на них реагування як з боку держави, так і з боку учасників фінансових відносин.

В. Коваленко слушно зазначає, що «... фiнансова сфера, постійно наповнюючись розмаїттям нових фінансових інструментів та їх похідних, постійно відтворює ризики, недооцінка яких (як підтвердила світова фінансова криза) зумовлює локальні та глобальні негаразди .... для сучасного фінансового ринку характерне посилення впливу факторів невизначеності, зумовлених використанням складних фінансових продуктів, які реально створюють додаткові системні ризики» [2, с. 31$]$.

За кримінально-правовою ознакою до числа кримінальних правопорушень «економічної спрямованості» доцільно віднести діяння, відповідальність за які передбачена різними нормами Кримінального кодексу України [3], які містяться в розділах проти власності та у сфері господарської діяльності, у сфері службової діяльності та професійної діяльності, пов'язаної з наданням публічних послуг [4, с. 414-416], зокрема:

- ст. 185 КК України «Крадіжка»;

- ст. 190 КК України «Шахрайство»;

- ст. 191 КК України «Привласнення, розтрата майна або заволодіння ним шляхом зловживання службовим становищем»;

- ст. 198 КК України «Придбання, отримання, зберігання чи збут майна, одержаного кримінально протиправним шляхом»;

- ст. 209 КК України «Легалізація (відмивання) доходів, одержаних злочинним шляхом»; 


\section{Кримінальне право, кримінальний процес та криміналістика}

- ст. 212 КК України «Ухилення від сплати податків, зборів (обов' язкових платежів)»;

- ст. 227 КК України «Умисне введення в обіг на ринку України (випуск на ринок України) небезпечної продукції»;

- ст. 229 КК України «Незаконне використання знака для товарів і послуг, фірмового найменування, кваліфікованого зазначення походження товару»;

- ст. 358 КК України «Підроблення документів, печаток, штампів та бланків, збут чи використання підроблених документів, печаток, штампів»;

- ст. 364 КК України «Зловживання владою або службовим становищем»;

- ст. 366 КК України «Службове підроблення»;

- ст. 369 КК України «Пропозиція, обіцянка або надання неправомірної вигоди службовій особі».

Виходячи 3 вищевикладеного, можна стверджувати, що незаконні дії службових та матеріально-відповідальних осіб у сфері економічної злочинності, пов'язані із:

- привласненням, розтратою майна або заволодінням ним шляхом зловживання службовим становищем;

- ухиленням від сплати податків, зборів, інших обов'язкових платежів;

- випуском або реалізацією недоброякісної продукції;

- корупційними та іншими протиправними діяннями.

Чинний Кримінальний кодекс України не виокремлюе розділу під назвою «Злочини у сфері економічної діяльності», а статті, які містять кримінальну відповідальність за фінансово-економічні правопорушення, репрезентовані у Розділі VI «Кримінальні правопорушення проти власності» та Розділ VII «Кримінальні правопорушення у сфері господарської діяльності». На нашу думку, у Кримінальний Кодекс України доцільно ввести окрему кримінально-правову категорію, дефініцію «кримінальні правопорушення у сфері економіки».

Основні риси фінансово-економічних правопорушень проявляються в тому, що їх скоюють у сфері легальної й нелегальної господарської діяльності; суб'єктами цих діянь можуть бути як підприємець, так і інші осо- би, які сприяють здійсненню господарської діяльності; вони наносять економічний, політичний, моральний збиток суспільству й державі; вони спрямовані на одержання економічної вигоди; їх скоюють тільки умисно; можуть вчинятися різними способами, передбаченими чинним кримінальним законодавством [5, с.11-12].

Протидія злочинності, охоплюе три сфери суспільних відносин:

1) загальна організація протидії злочинності - це сукупність організаційних (облік, реєстрація), управлінських (прогнозування, планування, координація, визначення стратегії і тактики), профілактичних (реалізація програм і планів, здійснення профілактичних заходів), контрольних (вивчення практики, встановлення тенденцій злочинності) та інших дій різноманітних органів та установ, які взаємодіють для досягнення спільних результатів;

2) правоохоронна діяльність - система заходів $з$ реалізації правоохоронних та/або правозастосовних функцій державними органами, громадськими об'єднаннями чи громадянами;

3) попередження злочинності - це здійснення спеціальними суб'єктами передбачених законом заходів для недопущення розвитку злочинного наміру на попередніх стадіях вчинення злочину, виявлення ознак вчинених діянь, встановлення осіб, які їх скоїли, притягнення цих осіб до відповідальності, відновлення порушених прав, свобод і законних інтересів громадян та відшкодування збитків від злочинних дій [6, с. 45].

Правоохоронну функцію у сфері економічних порушень бізнесу виконують податкова міліція, Служба безпеки України та Національна поліція України. За даними офіційної статистики Офісу Генерального прокурора, у 2019 році було зареєстровано 1287 кримінальних проваджень за ухилення від сплати податків. Водночас, на стадії досудового розслідування у поточному році вже було закрито 262 кримінальні провадження, 3 яких 259 - за відсутності складу/події кримінального правопорушення [7].

Результатами судового розгляду відповідних справ за попередній рік у Сдиному державному реєстрі судових рішень наявні 
всього 18 вироків, а саме: 10 обвинувальних вироків, із яких 3 - на підставі угод про визнання винуватості та 8 виправдувальних вироків [7]. Така статистика свідчить про недостатньо ефективну роботу, в першу чергу, так званої донедавна «податкової міліції», Бюро економічної безпеки, у розслідуванні економічних злочинів, необхідність позбавити правоохоронні органи від невластивих їм функцій та відокремити правоохоронну функцію від сервісної функції податкової.

Як стверджує С. С. Чернявський, для розслідування так званих «економічних злочинів» заходи мають бути спрямовані на: використання даних оперативних підрозділів, дослідження актів ревізій, аудиторських перевірок; одержання інформації від правоохоронних і контролюючих органів (підрозділів Державної фіскальної служби України, Бюро економічної безпеки, Національного банку України, Державної митної служби України та інших) [8, с. 639].

До загальних завдань, що вирішуються під час розслідування кримінальних правопорушень у сфері економіки, відносять:

1) визначення об'єкта посягання та предмета (сукупності об'єктів) кримінального правопорушення;

2) встановлення особи, яка вчинила суспільно небезпечне діяння;

3) апроксимація умов та способу вчинення кримінального правопорушення;

4) виявлення об'єкта «економічного» кримінального правопорушення;

5) відшкодування винною особою заподіяних збитків;

6) встановлення причин та умов, що сприяли вчиненню злочинного діяння.

Погоджуємось із позицією Канцір I. А. та Скорик Г. І. [9], які окреслюють превентивний інструментарій економічної злочинності:

- удосконалення понятійного апарату;

- уніфікація регуляторної політики у сфері права та економіки;

- дерегуляція повноважень та визначення механізму співпраці регуляторних органів;

- удосконалення норм чинного законодавства 3 метою впровадження нової культури ведення бізнесу та превенції проявам економічної злочинності;

- гарантування паритетних умов нормативного регулювання державного та недержавного секторів економіки.

\section{Висновки}

Кримінальні правопорушення у сфері економіки - це умисні суспільно небезпечні діяння проти права власності, встановленого порядку здійснення господарської та службової діяльності, що завдають шкоду суспільним економічним відносинам, законним правам та інтересам громадян і суб’єктів господарювання незалежно від форм власності.

Статистика свідчить про недостатньо ефективну роботу компетентних органів у розслідуванні економічних злочинів, необхідність позбавити правоохоронні органи від невластивих їм функцій та відокремити правоохоронну функцію від сервісної «функції податкової», правового, консультативного супроводу.

Абсолютно виправданим, доречним $є$ створення у 2021 році центрального органу виконавчої влади, на який покладається завдання щодо протидії правопорушенням, що посягають на функціонування економіки держави (Бюро економічної безпеки України).

Детективи Бюро економічної безпеки України (дізнавачі, слідчі) вже уповноважені в межах компетенції, визначеної Законом України «Про оперативно-розшукову діяльність» та Кримінальним процесуальним кодексом України, здійснювати оперативно-розшукову діяльність і досудове розслідування кримінальних правопорушень, віднесених законом саме до підслідності Бюро економічної безпеки України (кримінальних правопорушень, передбачених статтями $199,200,203^{-2}, 204,205^{-1}, 206,212,212^{-}$ $1,218^{-1}, 219,220^{-1}, 220^{-2}, 222,222^{-1}, 223$ 1, 224, 229, 231, 232, 232-1, 232-2 233 Кримінального кодексу України).

\section{Література}

1. Кримінальний процесуальний кодекс від 13.04.2012 № 4651-VI. URL: https:// 


\section{Кримінальне право, кримінальний процес та криміналістика}

zakon.rada.gov.ua/laws/show/2341-14 (дата звернення: 29.11.2021 р.).

2. Коваленко В. В. Фінансові ризики та шляхи їх мінімізації. Правовий аспект : монографія; за ред. А. Т. Ковальчука. К. : Знання, 2011.319 с.

3. Кримінальний кодекс України від 05.04.2001. № 2341-III. URL: https://zakon. rada.gov.ua/laws/show/2341-14 (дата звернення: 25.11.2021 р.).

4. Іванцова О. В. Особливості криміналістичної класифікації злочинів, що вчинюються у галузі цукрового виробництва. Традииї та новаиї юридичной науки: минуле, сучасність, майбутнє: матеріали Міжнародної науково-практичної конферениій (м. Одеса,19 травня 2017 р.) У 2-х т. Т. 2 / відп. ред. Г.О. Ульянова. Одеса: Видавничий дім «Гельветика». 2017. С. 414-416.

5. Кальман О. Г. Злочинність у сфері економіки України: теоретичні та прикладні проблеми попередження: дис. на здобуття наук, ступеня д-ра юрид. наук: спец. 12.00.08 «Кримінальне право та кримінологія; кримінально-виконавче право». Національна юридична академія України імені Ярослава Мудрого. Харків, 2004. $480 \mathrm{c}$

6. Бойко А. М. Детермінація економічної злочинності в Україні в умовах переходу до ринкової економіки (теоретико-кримінологічне дослідження) : монографія. Аьвів: Вид. центр ЛНУ ім. Івана Франка, 2008.$378 \mathrm{c}$.

7. Офіційний сайт Офісу Генерального прокурора. URL: https://www.gp.gov.ua; Єдиний державний реєстр судових рішень. URL: https://reyestr.court.gov.ua.

8. Чернявський С. С. Фінансове шахрайство: методологічні засади розслідування: монографія. Київ : Хай-Тек Прес. 2010. $624 \mathrm{c}$

9. Скорик Г. I., Канцір I. А. Новітня прадигма фінансово-економічної злочинності. Latest technologies of neo-industrial transfor-
The current structure of economic crime covers a significant proportion of crimes committed in the public sector. The purpose of mercenary crimes committed in the economic sphere is increasingly the withdrawal of funds from the treasury in legal forms of economic activity or the authority to control these activities using the official position of officials.

In globalization, transnational cooperation, transformational transformations of the national economy, the spread of economic crime, and criminalization of financial and economic relations is negative trend.

It had determined that economic crime is a selfish criminal activity of officials and other participants in economic relations aimed at causing material damage to enterprises, institutions, organizations of various ownership or business entities.

Based on the analysis of scientific research, the article formulates the main determinants of economic crime, had substantiated the material feature of financial and economical; correlations had established between the level of financial and economic crime and the low level of responsibility for committing this type of crime. A significant reason for committing economic crimes is a high degree of financial risk and insufficient response to them both by the state and by participants in financial relations.

It had proposed to implement in the Criminal Code of Ukraine the term "criminal offenses in the economic sphere» as intentional socially dangerous acts against property rights, the established procedure for economic and official activities that harm public economic relations, legal rights, and interests of citizens and businesses regardless of ownership.

Keywords: economic crime, crime in the economic sphere, criminal offenses in the economic sphere, financial resources, financial risks.

mations: financial, legal and sociological aspects: колективна монографія. Steyr : Shioda GmbH, Steyr, 2020. 380 c. C. 34-42. 